Çukurova Üniversitesi Mühendislik Fakültesi Dergisi, 36(2), ss. 535-546, Haziran 2021

Cukurova University Journal of the Faculty of Engineering, 36(2), pp. 535-546, June 2021

\title{
Ereğli-Ulukışla Arası Demiryolu Hattındaki Derin Kazı Şevlerinin Duraylılık İncelemesi
}

\author{
Selahattin YAPRAK ${ }^{1}$, Sedat TÜRKMEN*2 \\ ${ }^{1}$ Devlet Demiryolları 6. Bölge Müdürlüğ̈̈, Adana \\ ${ }^{2}$ Çukurova Üniversitesi, Mühendislik Fakültesi, Jeoloji Mühendisliği Bölümü, Adana
}

Geliş tarihi: 27.04.2021 Kabul tarihi: 30.06.2021

\section{$\ddot{\mathbf{O z}}$}

Çalışma, Devlet Demiryolları tarafından yapımı sürdürülen Ereğli-Ulukışla demiryolu güzergâhında Çakmak - Ulukışla İstasyonları arasında yer alan 9 km'lik güzergahtaki derin kazı çalışmalarını ve bu kazılardan dolayı oluşabilecek duraylılık sorunlarının araştırılmasını amaçlamaktadır. İnceleme alanında yer alan litolojik birimler, literatürde İnsuyu ve Cihanbeyli formasyonu olarak adlandırılan Pliyosen yaşlı karasal çökellerden meydana gelmektedir, $\mathrm{Bu}$ litolojik birimler başta silttaş1-marn-kiltaşı ardalanmasından oluşmakta, yüzeyde ise ayrışmadan dolayı kalın kil ve silt bir örtü yer almaktadır. Proje kriterlerine göre kazı şevlerinin durağan durumda güvenlik sayısı $>1,50$ ve depremli durumda ise güvenlik sayısı >1,10 koşullarını sağlaması öngörülmüştür. Çalışma alanındaki en derin kazının olduğu 3 farklı bölgede 2/3 (yatay/düşey) eğimli şevlerin yapılan duraylılık analizlerinde hem durağan durumda hem de deprem durumunda proje koşullarını sağlamadığı saptanmıştır. Aynı şevlerin, şev açıları 1/1 (yatay/düşey) ve 3/2 (yatay/düşey) olarak değiştirildiğinde yapılan analizlerinde duraylılık koşulunu sağladiğ 1 belirlenmiştir.

Anahtar Kelimeler: Ereğli, Ulukışla, Demiryolu, Derin kazı, Şev duraylılı̆̆ı

\section{Investigation of Stability of Deep Excavation Slopes in Ereğli-Ulukışla Railway Line}

\begin{abstract}
This study aims to investigate stability problems that may occur due to deep excavations on the $9 \mathrm{~km}$ route between Çakmak-Ulukışla Stations on the railway route between Ereğli-Ulukışla, which is under construction by the State Railways. The lithological units, where the study area is located, consist of Pliocene aged terrestrial sediments, which are called Insuyu and Cihanbeyli formations in the literature. These lithological units consist mainly of siltstone-marl-clay stone alternation, and on the surface there is a thick clay and silt cover due to weathering. According to the project criteria, it is envisaged that the cut slopes will meet the conditions of safety factor $>1.50$ in the static condition and of safety factor $>1.10$ in the earthquake condition. In the stability analyses conducted in 3 different regions which were the deepest excavations in the study area, in cut slopes with a slope of 2(horizontal): 3(vertical) the safety factor required was not met in both static and earthquake conditions. When the slope angles of the same cut slopes are improved to $1 / 1$ (horizontal/vertical) and 3/2 (horizontal/vertical), the stability analysis shows that the cut slopes are stable.
\end{abstract}

Keywords: Ereğli, Ulukışla, Railway, Deep Excavation, Slope stability

*Sorumlu yazar (Corresponding author): Sedat TÜRKMEN, sturkmen@cu.edu.tr 


\section{GIiRiş}

Çalışmanın amacı, Devlet Demiryolları tarafından yapımı sürdürülen Çakmak-Ulukışla İstasyonları $\mathrm{Km}: 217+000-226+000$ arasinda yer alan demiryolu güzergâhında derin yarma kazılarından dolayı oluşabilecek duraylılık sorunlarının araştırılmasıdır. Proje, Karaman İli ile Niğde İli Ulukışla İlçesi'ni birbirine bağlayan 200 km/saat ile hizmet verecek ve karayolu taşımacılığıyla yaklaşık 2,5 saat süren yol mesafesini 40 dakikaya indirecek hızlı tren projesidir. Proje, İç Anadolu'yu Akdeniz ve Mersin limanlarına bağlayarak daha önce Devlet Demiryolları tarafından yapılan Karaman-Konya-Ankara-Eskişehir-İstanbul yüksek hızlı tren hatları ile de entegre olacaktır (Şekil 1 ve 2).

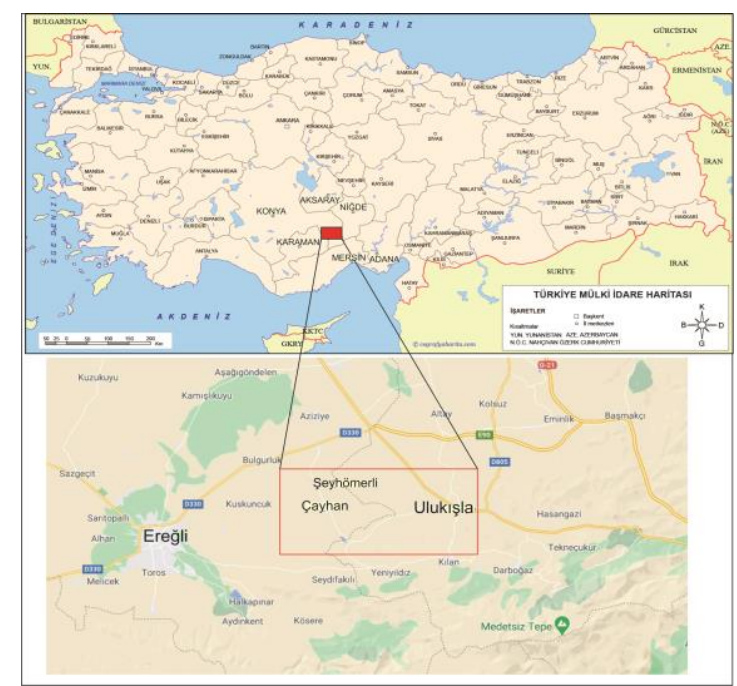

Şekil 1. Yer bulduru haritası

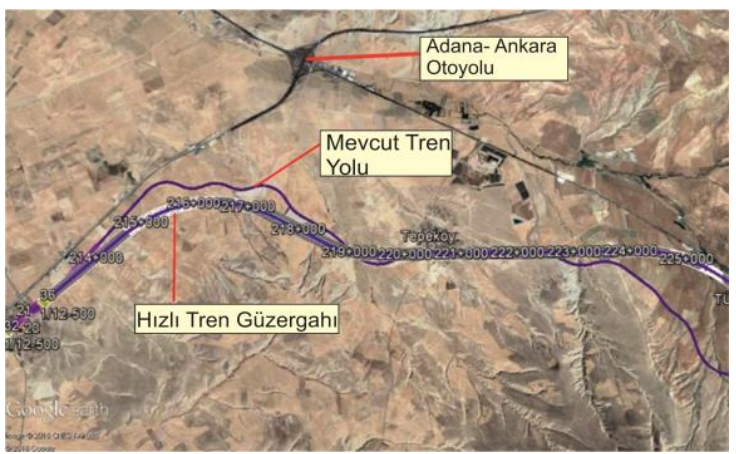

Şekil 2. İnceleme alanının uygu görüntüsü
Akdeniz üzerinden Mersin Limanına gelen yük taşımacılığının İç Anadolu Bölgesi'ne aktarılmasında karayolu taşımacılığının yükünü büyük ölçüde azaltacak ve yolcu taşımacılığında daha konforlu ve güvenli bir ulaşım imkânı sunacaktır. Karaman-Ulukışla hızlı tren projesi altyapı ve üstyapım işi toplam $2 \times 130 \mathrm{~km}$ uzunluğunda demiryolu projesidir. Projenin Çakmak ve Ulukışla İstasyonları arasındaki kısım yaklaşık 11 km'dir. Çakmak ve Ulukışla istasyonları arasındaki bu kesimde derin kazı alanları mevcuttur. Bu çalışmada yer alan derin kazı şevlerinin kazı eğimlerinin belirlenmesine yönelik Mühendislik Jeolojisi özelliklerinin değerlendirilmesi ve derin kazı şevlerinin duraylılığının incelenmesi çalışmanın amacını oluşturmaktadir.

\section{MATERYAL VE METOD}

\subsection{Materyal}

Çalışılan bölgede daha önce yapılan bilimsel araştırmalar, arazi harita işleri, sondajlar, araştırma çukurları, laboratuvar deneyleri incelemenin materyalini oluşturmaktadır [1-3].

Çalışma bölgesindeki litolojik birimler incelendiğinde başta silttaş1-marn-kiltaşı ardalanmasından oluşan Üst Miyosen -Pliyosen yaşlı karasal çökeller ile yüzeyde oluşan ayrışma ürünü kalın kil ve silt bir örtünün hakim olduğu gözlenir. Km: 217+000-226+000 arası derin yarma bölgelerinde formasyonların ve tabakaların benzerlik göstermesinden dolayı 3 farklı kritik kesit noktası belirlenmiş ve bu 3 farklı kritik kesitin duraylılık analizleri yapılmıştır, (Şekil 3-4).

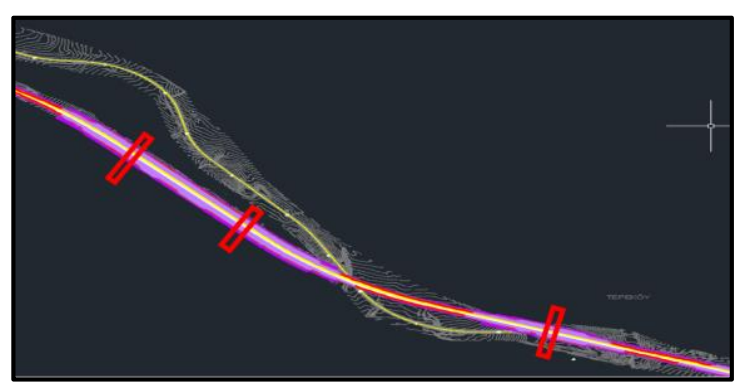

Şekil 3. Km:217+600-220+000 arası derin kazı güzergahı yerleşim planı 


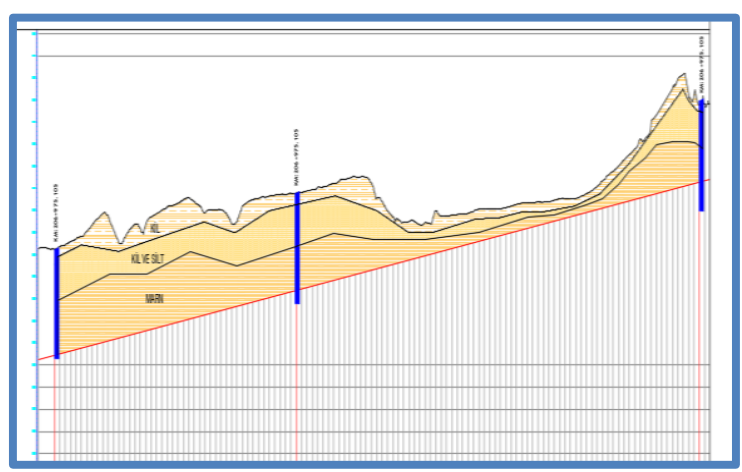

Şekil 4. Km: 217+600-220+000 arası derin kazı güzergahı jeolojik kesiti

Projede yaklaşı $11 \mathrm{~km}$ uzunluğundaki güzergahta kazı derinlikleri 25m-40 m arasında değişmektedir. Derin kazı şevlerinde duraylılık için değişik destekleme yöntemleri uygulanabilmektedir. Bu yöntemler, fore kazık, istinat duvarı, şevleri çelik hasır ve betonla kaplama, taş pere kaplama, zemin çivileri, şev açılarını değiştirme, bir veya birden fazla palyeli kazı gibi farklı seçenekler olarak sıralanabilir. $\mathrm{Bu}$ amaçla projelerde jeolojikjeoteknik koşullar, maliyet ve imalat kolaylığı göz önüne alınarak en uygun yöntem seçilmelidir.

\section{2. İnceleme Alanının Jeolojisi}

Ereğli-Ulukışla Havzası'nın doğu sınırını Aladağlar ve Ecemiş fayı, batı sınırını Bor hattında görülen Niğde masifi, güney sınırını ise Bolkar dağları oluşturmaktadır [1,4].

Bölge, Tersiyer başında, içinde volkanik bir ada yayının gelişmekte olduğu kapanan bir okyanus durumundadır. Kapanma, kuzeyden güneye ilerleyen Kıta-Ada yayı-Kıta çarpışması şeklinde gelişmiştir [5,6].

Bölgenin okyanusal niteliği Lütesiyen sonlarında sona ermiş ve Üst Eosen-Alt Miyosen zaman süreci içinde gelişen çukurlarda önce evaporitik, sonra tatlı su ve karasal kırıntılar depolanmıştır. Orta Miyosen'de bölge orojenik hareketlerle yeniden şekillenmiştir. Yörede Üst MiyosenPliyosen'de düşey hareketler ve iklim değişmesi ile akarsu-göl koşullarında yeni bir tortul devre gelişmiştir. $\mathrm{Bu}$ evrede kırıntılı ve karbonatlı sedimanlar çökelmiştir (Şekil 5). Birimler, Pliyosen sonlarında etkin düşey hareketlere bağlı olarak kuzeybatıya doğru eğilme ve açık kıvrım oluşturacak şekilde çok hafif bir deformasyon geçirmişlerdir [7].

İnceleme alanındaki Neojen birimler değişik araştırmacılar tarafından farklı formasyon adları ile tanımlanmıştır [6-9]. Bu çalışmada inceleme alanında yaygın olan Miyosen-Pliyosen yaşlı birimler İnsuyu formasyonu [10] ve Pliyosen yaşlı Cihanbeyli formasyonu tanımları uygun görülmüştür (Şekil 5).

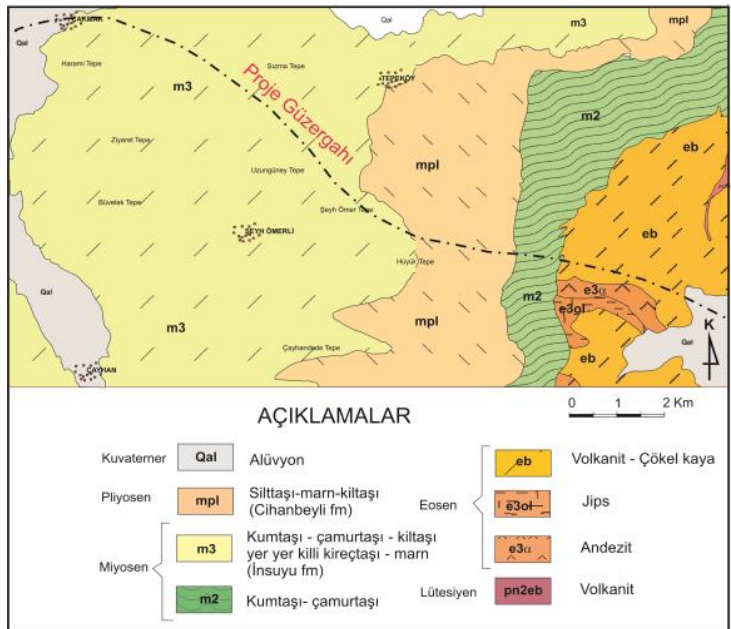

Şekil 5. İnceleme alanı ve çevresinin jeoloji haritas1 [11]

\section{İnsuyu Formasyonu:}

$\mathrm{Bu}$ formasyon güzergah boyunca 3 üye ile temsil edilmektedir. Bunlar;

- Beştepeler Üyesi: Killi kireçtaşı, çakıltaşı, şeyl

- Katrandedetepe Üyesi: Marn, kireçtaşı, kumtaş1, silttaşı

- Kızılbayır Üyesi: Çakıllı kil, kumtaşı, çakıltaşı, marn, kireçtaşı, şeyl.

Bu birim, Çakmak istasyonundan sonra başlayan derin yarma bölgesinin güneyine doğru Tepeköy Mahallesi ile Ulukışla arasında mostra vermekte olup, ayrıca güzergahın devamında Ulukışla İstasyonu civarı Km: 216+000-230+000 arasinda da gözlemlenmektedir. Genel olarak masif 
görünümlü olan birim, Tepeköy civarında ise yer yer tabakalı bir yapı sunar. Birimin en belirgin gözlendiği alanlar Tepeköy Mahallesi civarıdır. Formasyon içerisindeki farklı kayaçların dayanım özellikleri genel olarak düşük ve orta derecededir.

\section{Cihanbeyli Formasyonu:}

Ereğli-Ulukışla havzası ile Tuz Gölü havzası'nın birimleri üzerinde geniş bir yayılım gösteren formasyon Cihanbeyli Formasyonu olarak adlandırılmıştır. Bu litolojik birimler başta silttaşı marn - kiltaşı ardalanmasından oluşmakta, yüzeyde ise ayrışmadan dolayı kalın kil ve silt bir örtü yer almaktadır [7]. Formasyon Pliyosen yaşlı olup, karasal kırıntılardan meydana gelmektedir. Formasyon içinde marn ve kiltaşı tabakalarında ekonomik değeri olmayan linyit damarları görülmektedir [7]. Formasyondaki büyük ölçekli çapraz katmanlanma ile kırıntılardaki merceklenmeler akarsu ortamını, kireçtaşı ile bitümlü marnlar ise gölsel bir ortamın varlığını işaret etmektedir [8]. Bazı araştırıcılar bu birimi Altaylar, Ulukışla, Beştepeler adı altında adlandırmışlardır [6].

\section{Alüvyon:}

Çakıl, kum ve kilden oluşan alüvyon sı̆̆ olup, dere yataklarında izlenir. Ayrıca gevşek çimentolu veya çimentosuz yuvarlak taneli farklı birimlere ait çakıllar içeren çakıltaşı-kumtaşlarından meydana gelen taraça bulunmaktadır.

\subsection{Metod}

İnceleme; arazi öncesi çalışmalar, arazi çalışmaları, laboratuvar çalışmaları ve büro çalışmaları olmak üzere dört aşamada gerçekleştirilmiştir. Çalışması kapsamında; TCDD Yolları tarafından proje çalışmalarında hazırlanan raporlar ve jeoteknik amaçla yapılan sondajlardan ve laboratuvar deneylerinden yararlanılmıştır [2,3].

Kayma yüzeyinin stabilite analizlerinde Bishop, Janbu, Spencer, Sarma, Morgenstern - Price (GLE) vb. gibi yaygın limit denge metotları bulunmaktadır. $\mathrm{Bu}$ metotlarla Slide 2D yazılımı yardımıyla kaya ve/veya zeminden oluşan şevlerde güvenlik faktörü hesabı, dairesel ve dairesel olmayan yenilme yüzeylerin tespiti yapılabilmektedir. İnceleme alanı ve çevresinde yapılan kazı şevlerinde gözlenen kaymaların, ayrışmaya bağlı olarak dairesel şekilde geliştiği gözlenmiştir (Şekil 6,7). Bu gözleme dayalı olarak analizler, dairesel kayma olacak şekilde düşünülmüştür.

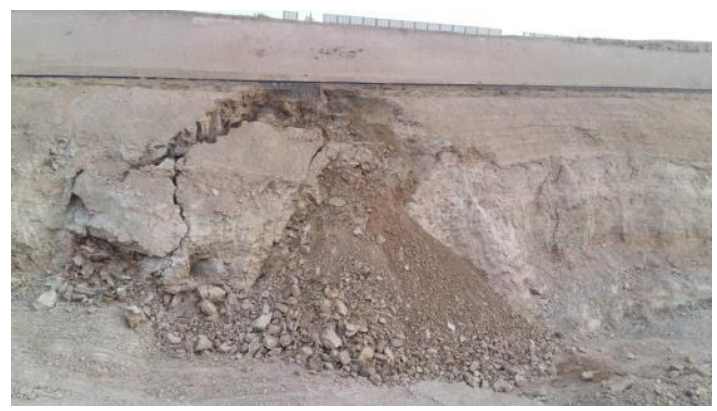

Şekil 6. Çalışma alanında izlenen dairesel kayma örnekleri

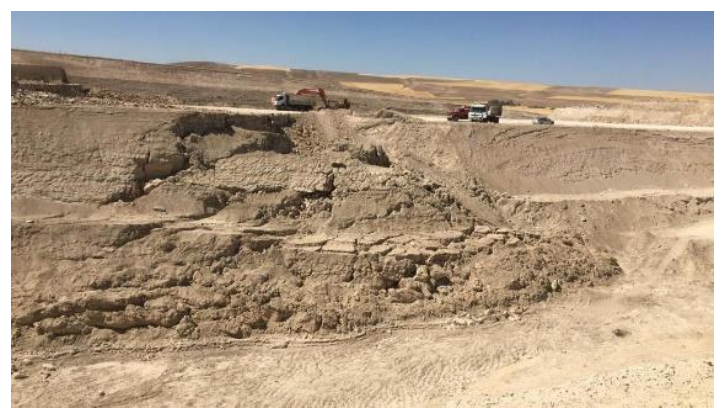

Şekil 7. Çalışma alanında izlenen dairesel kayma örnekleri

Limit denge analiz metodu, dairesel kayan bir kütlenin dilimlere ayrılarak hesap edilmesine dayanmaktadır [12,13]. İki boyutta limit denge analizlerinin uygulandığı bu metod, zaman içinde bilgisayar teknolojisindeki gelişmelere paralel olarak gelişerek daha kullanılır hale gelmiştir [1417]. Bu yöntemde kritik kayma dairesine ait şevde güvenlik katsayısı (GK), yerinde tutucu kuvvetlerin, şevi kaydırmaya çalışan kuvvetlere bölünmesi ile elde edilir. Basitleştirilmiş Bishop Yönteminde, şevlerin duraylılı̆̆ı limit denge eşitliğine dayanan dilimler yöntemi kullanmaktadır. Bu yöntemde potansiyel yenilme yüzeyi merkezi "O" olan, yarıçapı $\mathrm{r}$ olan bir daire parçası olarak kabul edilir. Daire merkezine göre 
moment denge koşullarında güvenlik katsayısının hesaplanma prensibini göz önüne alır. Güvenlik katsayısının 1 veya 1 'den büyük olduğu durumlarda $(\mathrm{GK} \geq 1)$, şevin dengede olduğu (stabil olduğu) kabul edilir.

Şev duraylılık analizleri Slide 2D bilgisayar yazılımı kullanılarak yapılmıştır. Önce incelenen şev kesitleri ve gerekli veriler yazılımlara tanıtılıp analizlere başlanmıştır. Litolojik birimlere ait kayma parametreleri ve arazi koşulları da eklenerek analizler yapılmıştır. Analizler sonucunda birkaç farklı senaryo üzerinde durulmuş ve bunlara yönelik iyileştirme çalışmaları önerilmiştir. En olumsuz koşullar da dikkate alınarak durağan ve depremli koşullara göre analizler gerçekleştirilmiştir.

Stabilite analizlerinde AFAD, Afet ve Acil Durum Yönetimi Başkanlığ 1 , Deprem Dairesi Başkanlığ tarafından hazırlanan Türkiye Deprem Tehlike Haritasından elde edilen pik yüzey ivmesi (PGA) $0.108 \mathrm{~g}$ değerleri dikkate alınmıştır [18]. Temel zeminin kaya litolojide olması dolayısıyla birinci tasarım deprem ivmesi-OBE ve ikinci tasarım deprem ivmesi-SSE kapsamında değerlendirilmesi yapılarak etkili olacak yatay yer ivmesi değerinin $0.050 \mathrm{~g}$ olacağı kabulü yapılmıştır.

\section{ARAŞTIRMA BULGULARI}

\subsection{Zeminlerin Mühendislik Özellikleri}

Km:217+000-226+000 arası güzergah üzerinde yapılan 17 adet sondaj ve alınan numuneler üzerinde yapılan deneyler sonrasında mühendislik jeolojisi parametreleri ortaya konmuş ve elde edilen değerler sonrasında büro çalışmaları kapsamında bilgisayar destekli yazılımlar sayesinde duraylılık analizleri yapılmıștır. Proje kriterlerine göre [2] yarma şevlerinin statik durumda güvenlik sayıs1 $>1,50$ ve depremli durumda ise güvenlik sayısı $>1,10$ koşullarını sağlaması öngörülmüştür.

Bu çalışma kapsamında en derin kazının yer aldığ 1 3 farklı bölgede seçilen kesit hatlarında $2 / 3$ (yatay/düşey), 1/1 (yatay/düşey) ve $3 / 2$ (yatay/düşey) eğimlerde kazı yapılacağı varsayılarak limit denge analizi ile duraylılık analizi yapılmıştır (Şekil 3 ve 4).

Zeminlerin mühendislik özelliklerinin belirlenmesi amaciyla inceleme alanından alınan numeneler üzerinde laboratuvar ortamında kıvam limitleri, elek analiz, su muhtevası, üç eksenli basınç deneyi, doğal birim hacim ağrılık deneyi ve konsolidasyon deneyleri yapılmıştır $[2,3,19]$.

Kil ve silt birimlerinde yapılan k1vam limitleri deneyi sonrası likit limit (LL) \%28,2-67,7, plastik limit (PL) \%16,3-27,1 ve plastisite indisi (PI) $\% 15,5-40,6$ aralığında bulunmuştur. Elek analizi ve atterberg limitleri deneyi sonucunda Birleştirilmiş Zemin Sinıflamasına Göre zemin sınıfı "CH-CL" (Yüksek Plastiseli Kil-Düşük Plastisiteli Kil) olarak belirtilmiştir.

\subsection{Sayısal Modelleme}

İnceleme bölgesinde yapılan sondajlar sonrası laboratuvar deneylerinden üç eksenli basınç deneyi yapılarak, içsel sürtünme açısı ve kohezyon değerleri ortaya çıkarılmıştır. Laboratuvar deney sonuçları ile mühendislik jeolojisi değerleri elde edilmiş olup, Çizelge 1 'de verilmiştir.

Çizelge 1. Laboratuvar deneyleri sonuçları ve şev duraylılı̆̆ı analizlerinde kullanılacak değerler

\begin{tabular}{|c|c|c|c|c|c|c|}
\hline Litoloji & $\begin{array}{l}\gamma \quad \text { kuru } \\
\left(\mathrm{kN} / \mathrm{m}^{3}\right)\end{array}$ & $\begin{array}{c}\gamma \text { doygun } \\
\left(\mathrm{kN} / \mathrm{m}^{3}\right)\end{array}$ & $\mathrm{C}(\mathbf{k P a})$ & $\phi\left(^{\circ}\right)$ & $\mathbf{E}(\mathbf{k P a})$ & $\mathbf{R u}$ \\
\hline Kil & 18,00 & 19,00 & 10,00 & 30 & $40 \times 103$ & 0,15 \\
\hline Marn & 24,00 & 24,00 & 93,00 & 29 & $195 \times 103$ & 0,15 \\
\hline Zayıf Marn & 23,00 & 23,00 & 67,00 & 24 & $95 \times 103$ & 0,15 \\
\hline Marn & 23,00 & 23,00 & 77,00 & 26 & $132 \times 103$ & 0,15 \\
\hline
\end{tabular}




\subsection{1. Șev Duraylılık Analizleri}

\subsubsection{Km:217+600 Slide 2D Şev Stabilite Analizi}

İlk çalışma bölgesinin (Km:217+600) birinci senaryosunda projenin şev eğimleri $2 / 3$ (yatay/düşey) olarak tasarlanmış, ikinci senaryosunda ise alt palyelerin şev eğimleri $1 / 1$ (yatay/düşey) üst palye şev eğimi ise $3 / 2$ (yatay/düşey) olarak depremli ve depremsiz analizler yapılmıştır.

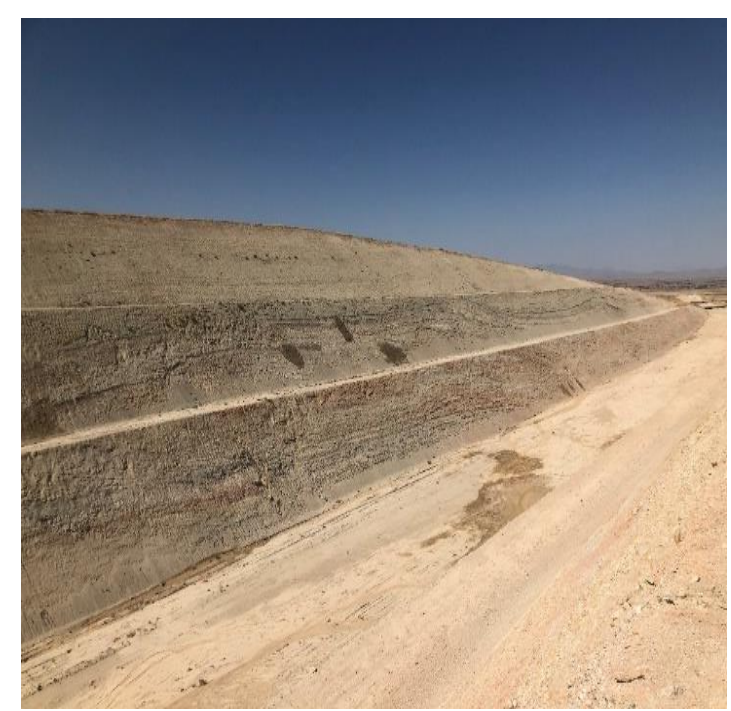

Şekil 8. Km: 217+600 kesitinde güney (sağ) şevler

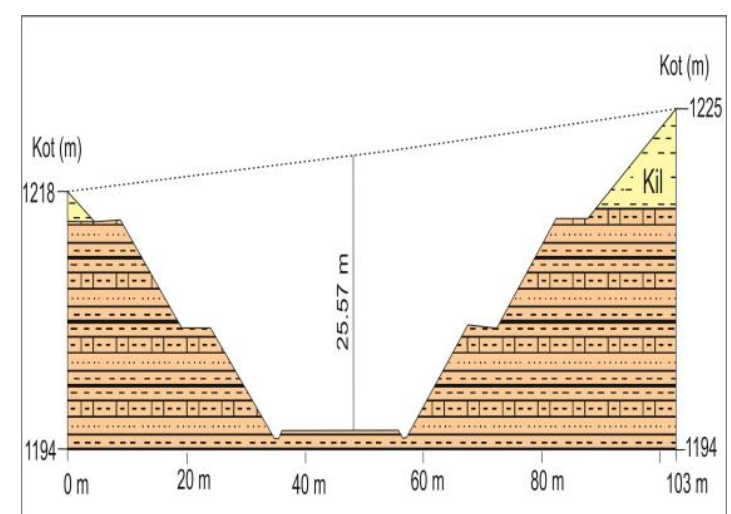

Şekil 9. Km: $217+600$ yan şevlerin kesiti ve tabakaların gösterimi

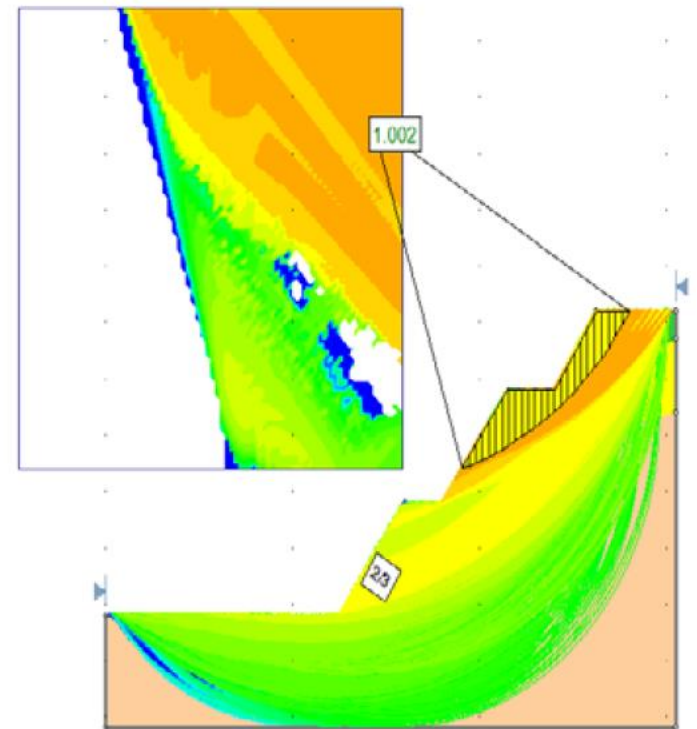

Şekil 10. Km: 217+600 kesitinde depremsiz sağ şev (2/3) için stabilite analizi (GK:1,002)

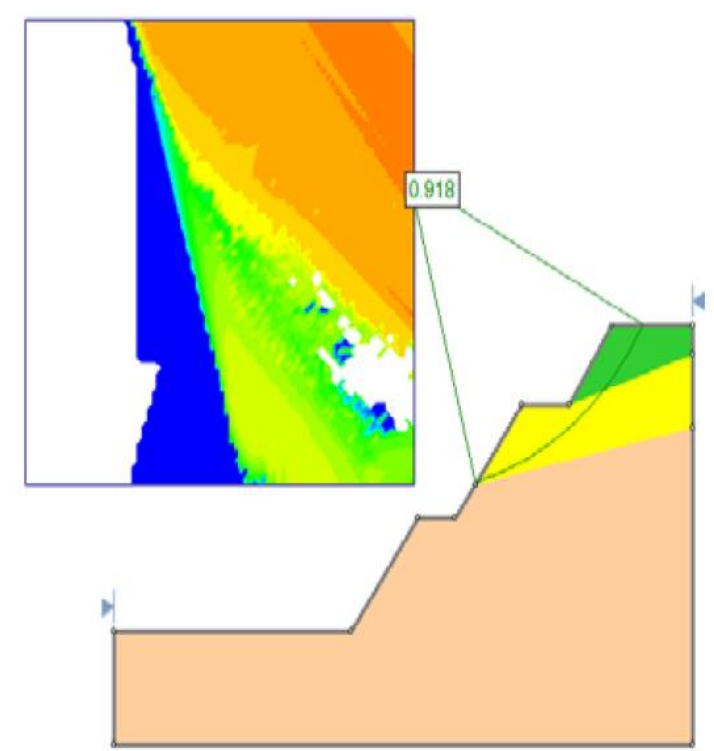

Şekil 11. Km:217+600 kesitinde depremli sağ şev (2/3) için stabilite analizi (GK:0,918)

Uzun dönem statik durumda ve depremli durumda 2/3 eğimli analizi tamamlanan şevlerin proje kriterlerini sağlamadığı ve şevlerin duraylı olmadığ1 görülmüştür. 


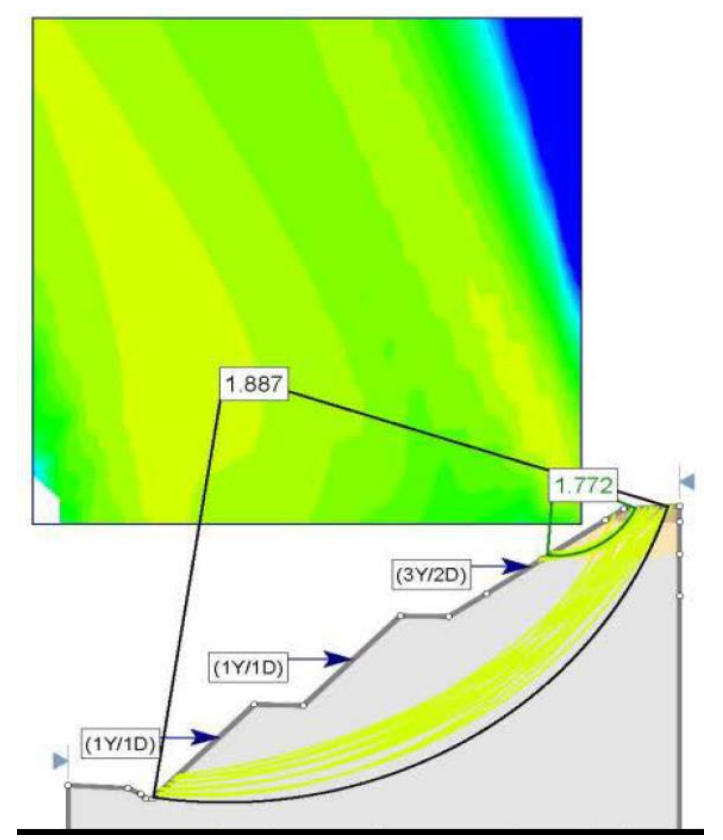

Şekil 12. Km: $217+600$ kesitinde depremsiz sağ şev (alt palyeler 1/1 üst palye 3/2) için duraylıl1k analizi (GK:1,77)

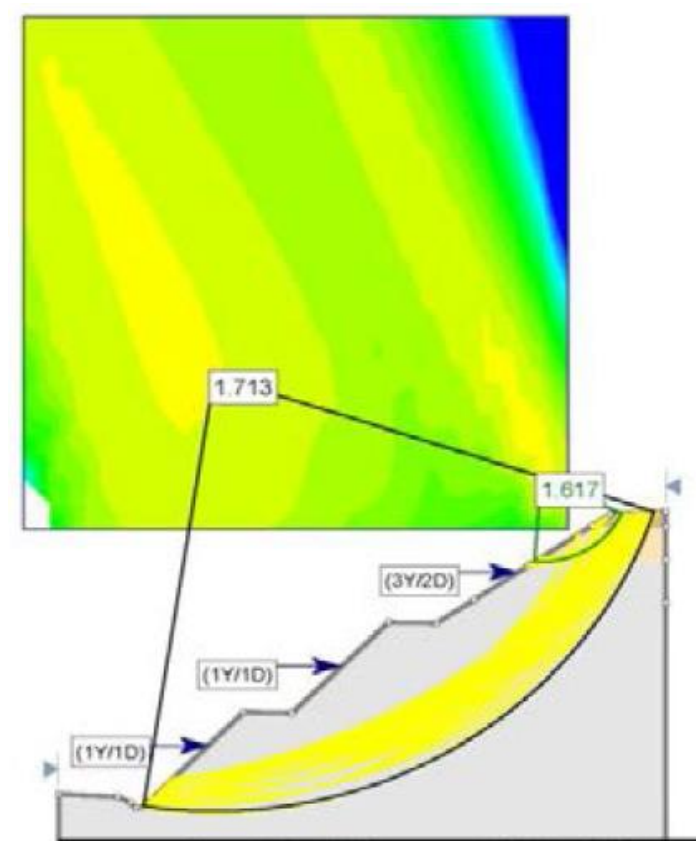

Şekil 13. Km: 217+600 kesitinde depremli sağ şev (alt palyeler $1 / 1$ üst palye $3 / 2$ ) için duraylılık analizi $(\mathrm{GK}: 1,617)$
Uzun dönem statik durumda ve depremli durumda $1 / 1$ ve $3 / 2$ eğimli analizi tamamlanan şevlerin proje kriterlerini sağladığ 1 ve şevlerin duraylı olduğu görülmüştür.

\subsubsection{Km:218+500 Slide 2D Şev Stabilite Analizi}

İkinci çalışma bölgesi $\mathrm{Km}: 218+500$ ' ün birinci senaryosunda projenin şev eğimleri $2 / 3$ (yatay/düşey) olarak oluşturulmuş, ikinci senaryosunda ise alt palyelerin şev eğimleri $1 / 1$ (yatay/düşey) üst palye şev eğimi ise $3 / 2$ (yatay/düşey) olarak depremli ve depremsiz analizler yapılmıştır. İkinci senaryoda Slide2D yazılımında analizi yapılan çalışmaların görüntüleri Şekil 14-18'de gösterilmiştir.

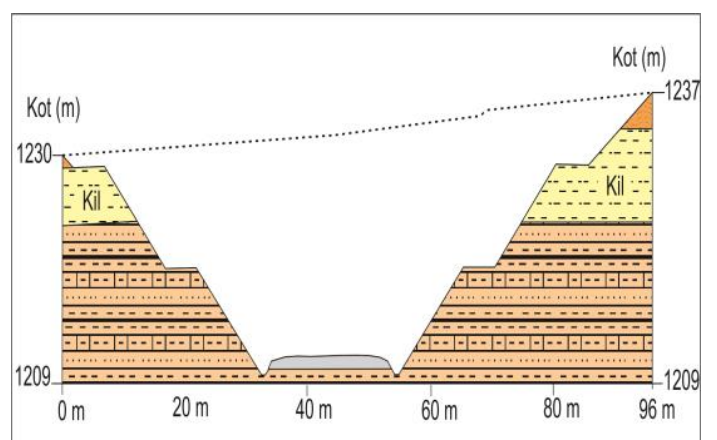

Şekil 14. Km: 218+500 yan şevlerin kesiti ve tabakaların gösterimi

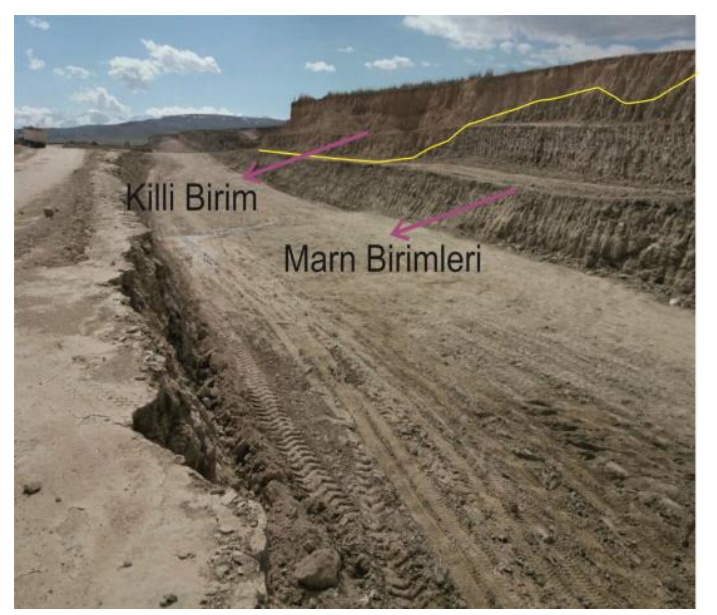

Şekil 15. Km: $218+500$ bölgesi killi birim ile marn arasındaki dokanak sinırı 


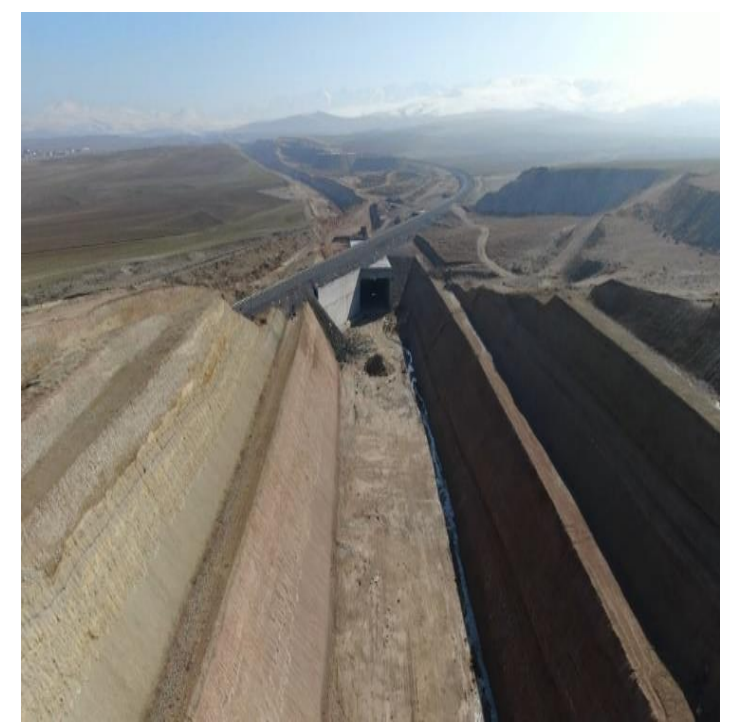

Şekil 16. Km: 218-500- $219+00$ civarı şev çalışma bölgesi ve aç kapa sanat yapısı görüntüsü

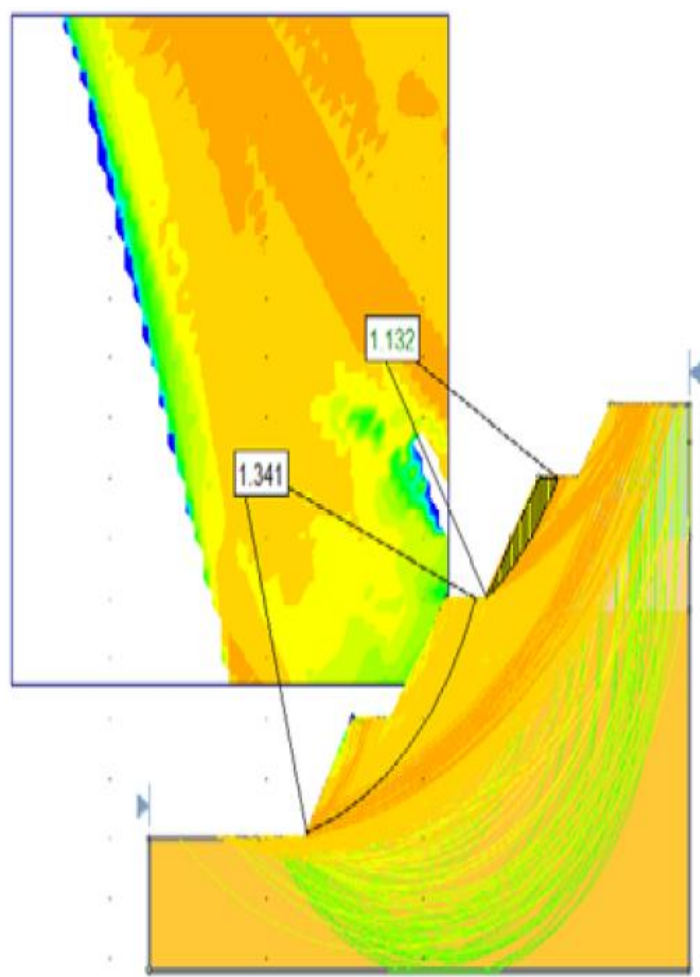

Şekil 17. Km: $218+500$ kesitinde depremsiz güney (sağ) şev (2/3) için desteksiz duraylılık analizi $(\mathrm{GK}: 1,13)$

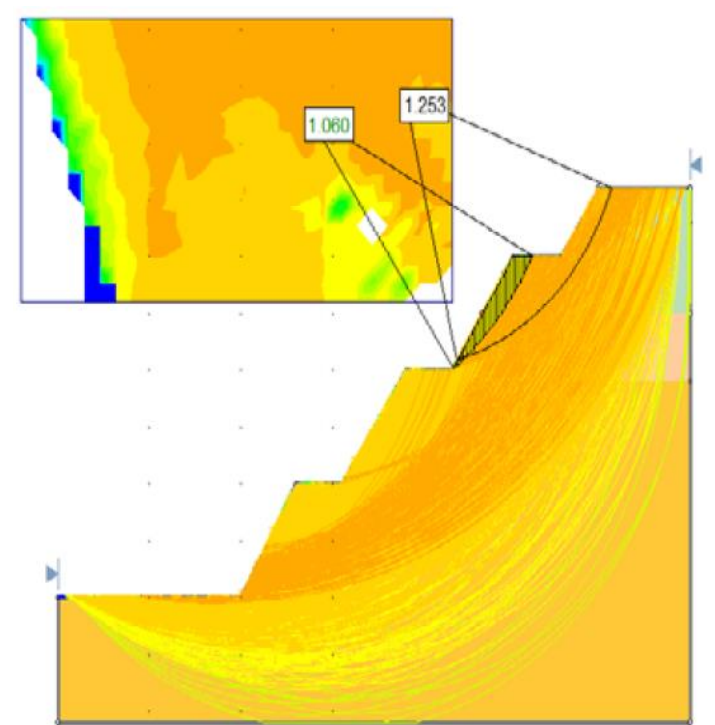

Şekil 18. Km: $218+500$ kesitinde depremli güney (sağ) şev (2/3) için desteksiz duraylılık analizi ( GK:1,06)

Uzun dönem statik durumda ve depremli durumda 2/3 eğimli analizi tamamlanan şevlerin proje kriterlerini sağlamadığı ve şevlerin duraylı olmadığ1 görülmüştür.

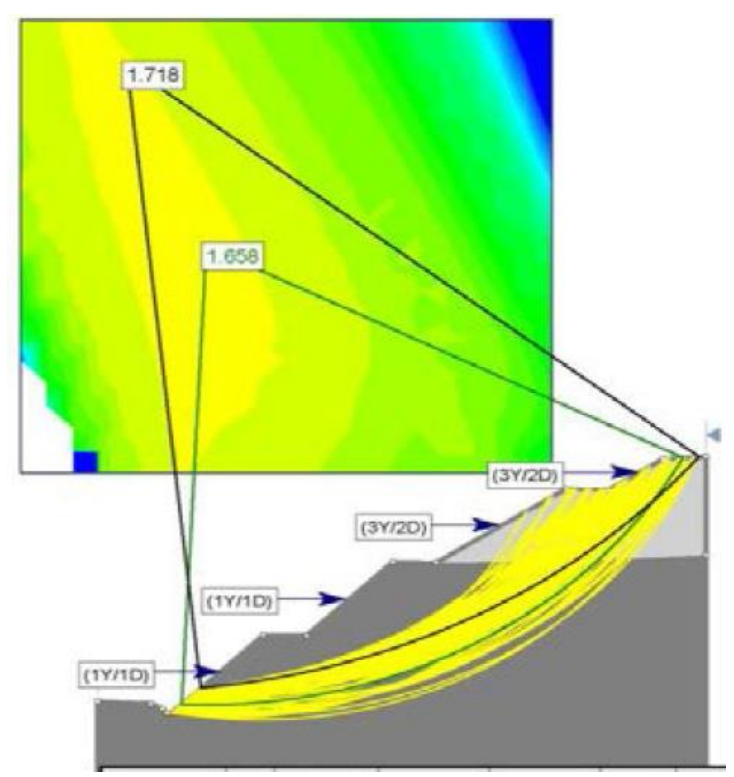

Şekil 19. Km: $218+500$ kesitinde depremsiz să̆ şev (alt palyeler 1/1 üst palye 3/2) için desteksiz duraylılık analizi (GK:1,65)

Ç.Ü. Müh. Fak. Dergisi, 36(2), Haziran 2021 


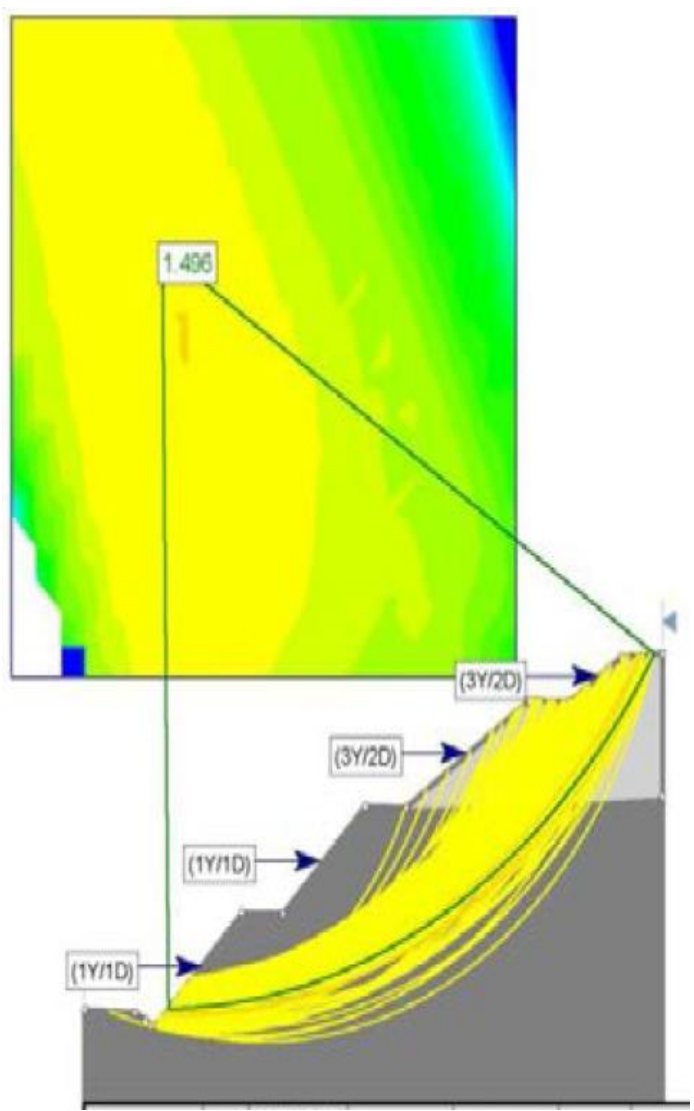

Şekil 20. Km: $218+500$ kesitinde depremli sağ şev (alt palyeler $1 / 1$ üst palye 3/2) için desteksiz duraylılık analizi (GK:1,496)

Uzun dönem statik durumda ve depremli durumda 2/3 eğimli analizi tamamlanan şevlerin proje kriterlerini sağlamadığı ve şevlerin duraylı olmadığı görülmüştür.

\subsubsection{Km:220+000 Slide 2D Sev Stabilite Analizi}

Üçüncü çalışma bölgesi olan Km:220+000'ın birinci senaryosunda projenin şev eğimleri $2 / 3$ (yatay/düşey) olarak oluşturulmuş, ikinci senaryoda ise alt palyelerin şev eğimleri $1 / 1$ (yatay/düşey) üst palye şev eğimi ise $3 / 2$ (yatay/düşey) olarak depremli ve depremsiz analizler yapılmıştır. İkinci senaryoda Slide2D yazılımında analizi yapılan çalışmaların görüntüleri Şekil 21-26’da gösterilmiştir.

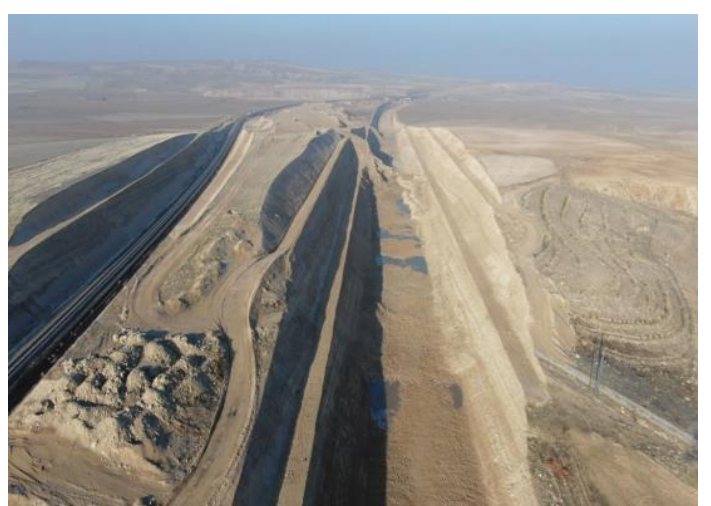

Şekil 21. Km:220+000 kazı şevlerinin görünümü

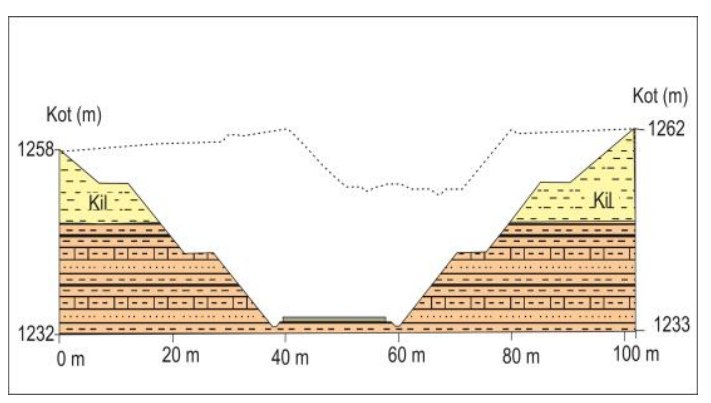

Şekil 22. Km:220+000 yan şevlerin kesiti ve tabakaların gösterimi

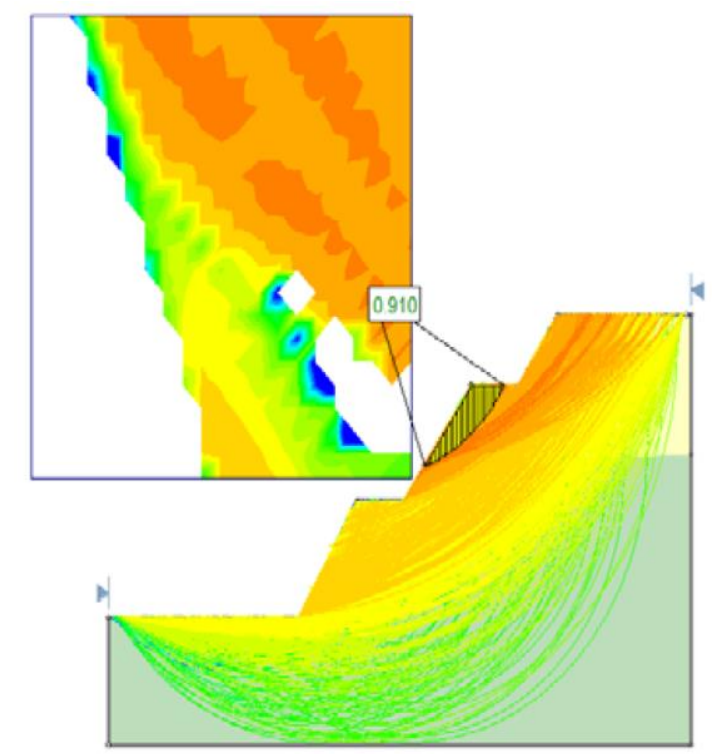

Şekil 23. Km:220+000 kesitinde depremsiz güney (sağ) şev (2/3) için duraylılık analizi (GK:0,91) 


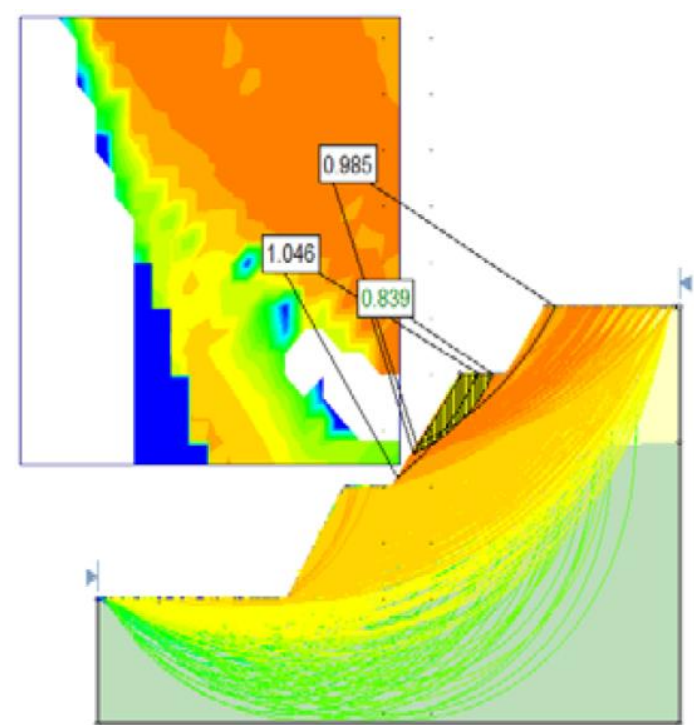

Şekil 24. Km:220+000 kesitinde depremli güney (sağ) şev (2/3) için duraylılık analizi (GK:0,83)

Uzun dönem statik durumda ve depremli durumda 2/3 eğimli analizi tamamlanan şevlerin proje kriterlerini sağlamadığı ve şevlerin duraylı olmadığı görülmüsştür.

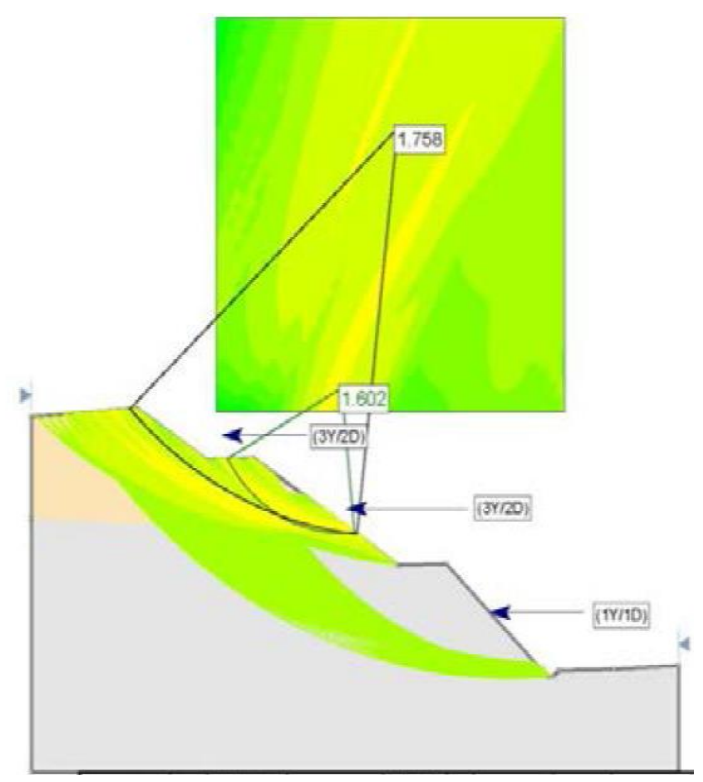

Şekil 25. Km:220+000 kesitinde depremsiz kuzey (sol) şev (alt palye 1/1 üst iki palye 3/2) için duraylılık analizi (GK:1,60 )

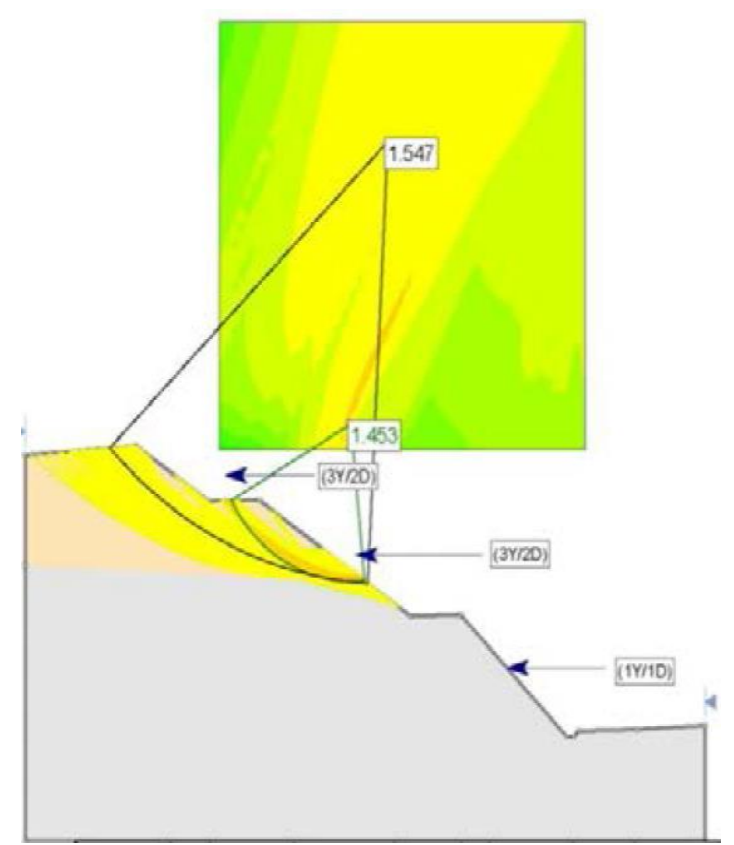

Şekil 26. Km:220+000 kesitinde depremli kuzey (sol) şev (alt palye 1/1 üst iki palye 3/2) için duraylılık analizi $(\mathrm{GK}: 1,45)$

Uzun dönem statik durumda ve depremli durumda 2/3 eğimli analizi tamamlanan şevlerin proje koşullarını sağlamadığı ve şevlerin duraylı olmadığı görülmüştür.

\section{SONUÇ VE ÖNERILLER}

217+600 kritik kesitinin birinci senaryosunda bütün şev açları 2/3 (yatay/düşey), ikinci senaryoda ise alt şevler 1/1 (yatay/düşey), üst şev ise $3 / 2$ (yatay/düşey) olacak şekilde öncelikle statik daha sonra depremli şekilde analiz yapılmıştır. $217+600$ kritik kesitinin birinci senaryosunda şev analizleri uzun dönem statik koşulda en küçük GK:1,002 uzun dönem deprem durumunda ise en küçük GK:0,918 olarak hesaplanmıştır. Depremli GK $<1,10$ olduğu için şevlerde duraysızlık söz konusudur. 217+600 kritik kesitinin ikinci senaryosunda uzun dönem statik koşulda en küçük GK:1,77 uzun dönem deprem durumunda ise en düşük GK:1,61 olarak bulunmuştur. Uzun dönem depremli $\mathrm{GK}>1,10$ uzun dönem statik $G K>1,50$ olduğu için şevlerde duraysızlık söz konusu değildir. 
218+500 kritik kesitinin birinci senaryosunda bütün şev açıları 2/3 (yatay/düşey), ikinci senaryosunda ise alt şevler 1/1 (yatay/düşey), üst şev ise 3/2 (yatay/düşey) olacak şekilde öncelikle statik daha sonra depremli şekilde analiz yapılmıştır. $218+500$ kritik kesitinin birinci senaryosunda şev analizleri uzun dönem statik koşulda en küçük GK:1,13 uzun dönem deprem durumunda ise en küçük GK:1,06 olarak hesaplanmıştır. Uzun dönem depremli $\mathrm{GK}<1,10$ ve uzun dönem statik $\mathrm{GK}<1.50$ olduğu için şevlerde duraysızlık söz konusudur. 218+500 kritik kesitinin ikinci senaryosunda şev analizi uzun dönem statik koşulda en küçük GK:1,65 uzun dönem deprem durumunda ise en küçük GK:1,496 olarak hesaplanmıştır. Uzun dönem depremli $G K>1,10$ ve uzun dönem statik $\mathrm{GK}>1,50$ olduğu için şevlerde duraysızlık söz konusu değildir.

220+000 kritik kesitinin birinci senaryosunda bütün şev açıları 2/3 (yatay/düşey), ikinci senaryoda ise alt şev 1/1 (yatay/düşey), üst şev ise $3 / 2$ (yatay/düşey) olacak şekilde öncelikle uzun dönem statik daha sonra uzun dönem depremli şekilde analiz yapılmıştır. 217+600 kritik kesitinde birinci senaryonun uzun dönem statik koşulda en küçük GK:0,91 uzun dönem deprem durumunda ise en küçük GK:0,83 olarak hesaplanmıştır. Uzun dönem depremli $\mathrm{GK}<1,10$ ve uzun dönem statik $G K<1,50$ olduğu için şevlerde duraysızlık söz konusudur. 220+000 kritik kesiti ikinci senaryosunda uzun dönem statik koşulda en küçük GK:1,60 uzun dönem deprem durumunda ise en küçük GK:1,45 olarak hesaplanmıştır. Uzun dönem depremli GK>1,10 ve uzun dönem statik $G K>1,50$ olduğu için şevlerde duraysızlık söz konusu değildir.

Çizelge 2 ve 3'de seçilen kesit hatlarında uygulanan her iki senaryonun duraylılık analiz sonucu elde edilen güvenlik sayıları toplu olarak gösterilmiştir.

Yarmalarda şev iyileştirme alternatifleri olarak fore kazık, istinat duvarı, şevleri çelik hasır ve betonla kaplama, taş pere kaplama, zemin çivileri, şev açılarını değiştirme gibi farklı alternatif imalatlar günümüzde kullanılmaktadır. İnceleme kapsamında çalıșılan bölgelerde bulunan yarmalar $25 \mathrm{~m}-40 \mathrm{~m}$ arası derinlikte, iki ve daha fazla palyelerden oluşmakta ve yaklaşık $11 \mathrm{~km}$ uzunluğundadır. Gözlemlenen bu durumlar dikkate alındığında şevler de alternatif iyileştirme yöntemleri içinde Jeoteknik açıdan duraylılığın sağlanabilmesi için; imalat kolaylığı, kısa zamanda yapılması, diğer seçeneklere göre ekonomik olması gibi nedenlerden dolayı şev açılarında iyileştirmeler yapılması en uygun seçenek olarak önerilmektedir.

Çizelge 2. Şev açıları 2/3(yatay/düşey) olarak gerçekleştirilen duraylılık analiz sonuçları

\begin{tabular}{|l|c|c|}
\hline \multirow{2}{*}{ Kesit hatları } & \multicolumn{2}{|c|}{ Güvenlik sayısı } \\
\cline { 2 - 3 } & Statik & Dinamik \\
\hline Km: $217+600$ & 1,002 & 0,918 \\
\hline Km: $218+500$ & 1,13 & 1,06 \\
\hline Km: $220+000$ & 0,91 & 0,83 \\
\hline
\end{tabular}

Çizelge 3. Üst şevler 3/2(yatay/düşey), alt şevler 1/1(yatay/düşey) olarak gerçekleştirilen duraylılık analiz sonuçları

\begin{tabular}{|l|c|c|}
\hline \multirow{2}{*}{ Kesit hatları } & \multicolumn{2}{|c|}{ Güvenlik sayısı } \\
\cline { 2 - 3 } & Statik & Dinamik \\
\hline Km: $217+600$ & 1,77 & 1,61 \\
\hline Km: $218+500$ & 1,65 & 1,496 \\
\hline Km: $220+000$ & 1,60 & 1,45 \\
\hline
\end{tabular}

\section{KAYNAKLAR}

1. Demirtaşlı, E., Bilgin, A. Z., Erenler, F., Işılar, S., Sanlı, D., Selim, N. ve Turhan, N. 1973. Bolkardağlarının Jeolojisi, Cumhuriyetin 50. Yılı Yerbilimleri Kongresi, Tebliğler, MTA Yayını, Ankara, 608.

2. TCDD, 2015. Demiryolu Güzergah JeolojikJeoteknik-geoteknik Etütlerinin Yapılmasına Ait Mühendislik Hizmetleri Teknik Şartnamesi, Ankara, 25.

3. TCDD, 2017. Karaman-Ulukışla İstasyonları Arası Hizlı Tren Projesi, Yarma Şevleri Geoteknik Değerlendirme Raporu, Ankara, 90-94.

4. Ketin, İ., Akarsu, R., 1965. Ulukışla Tersiyer Havzasının Jeolojik Etüdü Hakkında Rapor, TPAO, No: 339 
5. Ayhan, A., Sevin, M., Altun, İ.E., 1986. Karapınar-Ereğli (Konya)-Ulukışla (Niğde) Civarının Jeolojisi, Maden Tetkik ve Arama Genel Müdürlüğü, Derleme No: 8090 (yayımlanmamış).

6. Oktay F., 1982. Ulukışla ve Çevresinin Stratigrafisi ve Jeolojik Evrimi, Türkiye Jeoloji Kurumu Bülteni, Ankara, 25, 15-23.

7. Dellaloğlu, A.A., Aksu, R., 1986. Ereğli (Konya)-Ulukışla-Çiftehan-Çamardı (Niğde) Dolayının Jeolojisi ve Petrol Olanakları, TPAO. Rapor No: 2205. Ankara.

8. Sonel, N., Sarı, A., 2004., Ereğli-Ulukışla (Konya-Niğde) Havzasının Hidrokarbon Potansiyelinin İncelenmesi, Gazi Üniversitesi Mühendislik Mimarlık Fakültesi Dergisi, 19(4), 393-403.

9. Özdemir, A., 2006. Ereğli-Ulukışla Havzası Güney Formasyonunun Jeolojisi ve Petrol Hazne Kaya Özelliklerinin İncelenmesi, Ankara Üniversitesi, Fen Bilimleri Enstitüsü, Yüksek Lisans Tezi, Ankara, 94.

10. Kadınkız, G., Pekgöz, M., Karakaş, M., Murat, A., 2017. Tersiyer (Üst Miyosen-Pliyosen) Katrandedetepe Formasyonunda Sodyum Sülfat (Globerit-Blödit)-Halit Birlikteliği, Ereğli-Bor Havzasi, Türkiye. MTA Dergisi, Ankara, 154, 137-158.

11. MTA, 2002. $1 / 500000$ Ölçekli Türkiye Jeoloji Haritası (Adana Bölümü), MTA Genel Müdürlüğü, Ankara.

12. Fellenius, W., $1927 . \quad$ Erdstatische Berechnungen mit Reibung und Kohasion (Adhasion) und unter Annahmekreiszylindrischer Gleitflachen, Ernst \& Sohn, Berlin.

13. Bishop, W., 1955. The Use of the Slip Circle in the Stability Analysis of Slopes, Géotechnique, 5(1), 7-17.

14. Spencer, E., 1967. A Method of Analysis of the Stability of Embankments Assuming Parallel Inter-Slice Forces Géotechnique, 17(1), 11-26.

15. Nash, D.F.T., 1987. A Comparative Review of Limit Equilibrium Methods of Stability Analysis, In Anderson, M.G.

16. Morgenstern, N.R., 1992. The Evaluation of Slope Stability-a 25 Year Perspective, In Stability and Performance of Slopes and
Embankments, Geotechnical Special Publication 31, ASCE, New York, 1, 1-26.

17. Duncan, J.M., 1996. State of the Art: Limit Equilibrium and Finite Element Analysis of Slopes, ASCE J. of Geotech. Eng., 122(7), 577-591.

18. AFAD, 2018. Afet ve Acil Durum Yönetimi Başkanlığı Deprem Dairesi Başkanlığı, Türkiye Deprem Tehlike Haritas1.

19. ASTM (American society for testing and materials), 1994. Annual Book of ASTM Standarts-Section 4, Construction, V. 0408 Soil and Rock; Building Stones. ASTM Publication. 